JOURNAL OF ETHNOBIOLOGY

AND ETHNOMEDICINE

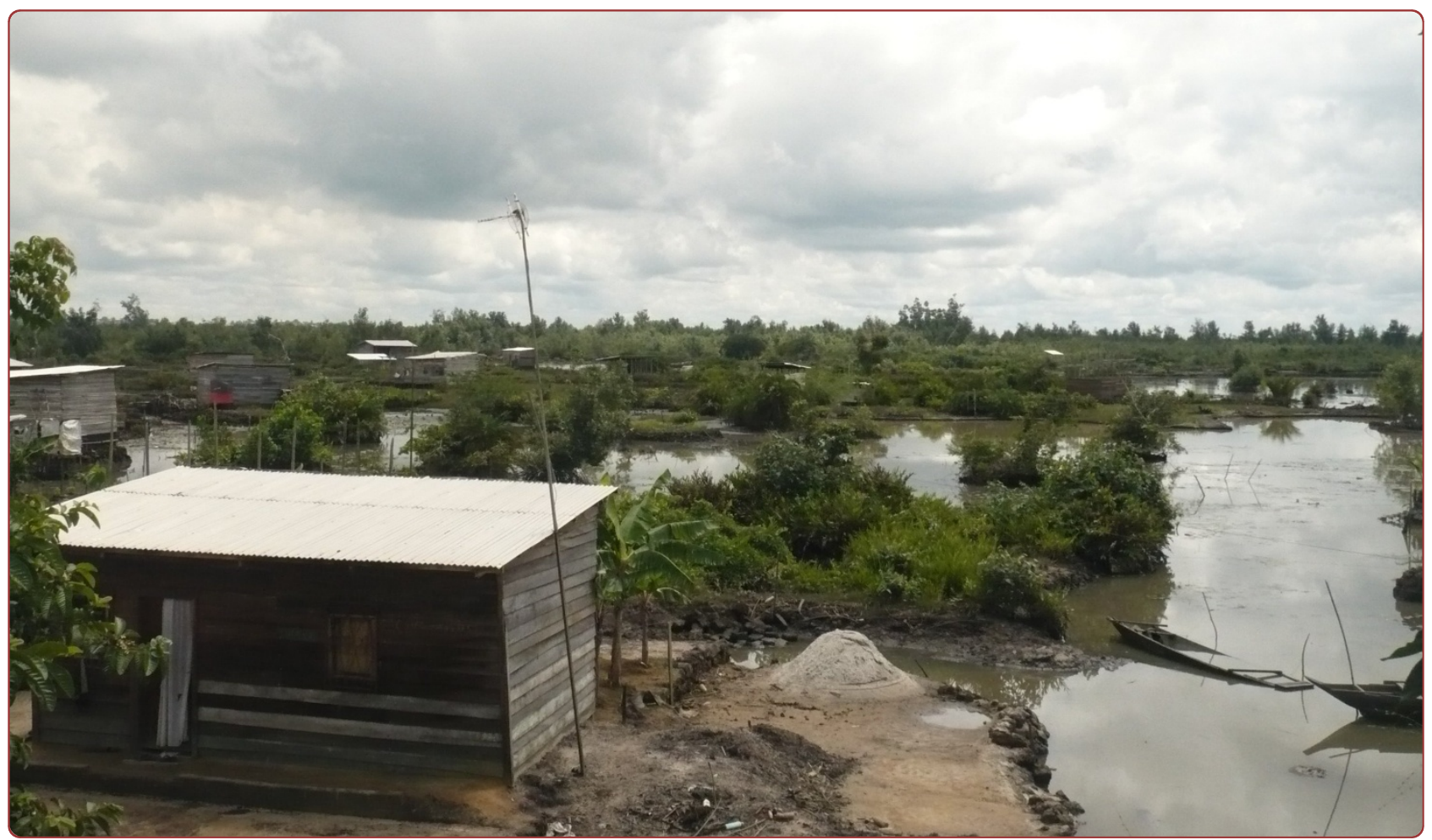

Assessing forest products usage and local residents' perception of environmental changes in peri-urban and rural mangroves of Cameroon, Central Africa

Nfotabong-Atheull et al. 


\title{
Assessing forest products usage and local residents' perception of environmental changes in peri-urban and rural mangroves of Cameroon, Central Africa
}

Adolphe Nfotabong-Atheull ${ }^{1,2,3^{*}}$, Ndongo Din ${ }^{2}$, Léopold G Essomè Koum², Behara Satyanarayana ${ }^{1,4,5}$, Nico Koedam ${ }^{4}$ and Farid Dahdouh-Guebas ${ }^{1,4}$

\begin{abstract}
Background: Deforestation is one of the most ubiquitous forms of land degradation worldwide. Although remote sensing and aerial photographs can supply valuable information on land/use cover changes, they may not regularly be available for some tropical coasts (e.g., Cameroon estuary) where cloud cover is frequent. With respect to mangroves, researchers are now employing local knowledge as an alternative means of understanding forest disturbances. This paper was primarily aimed at assessing the mangrove forest products usage, along with the local people's perceptions on environmental changes, between Littoral (Cameroon estuary) and Southern (mouth of the Nyong River and Mpalla village) regions of Cameroon.
\end{abstract}

Methods: The data from both locations were obtained through conducting household interviews and field observations.

Results: In the Cameroon estuary (Littoral region), 69.23\% of respondents (mostly elders) could distinguish two to four mangrove plants, whereas the informants (65.45\%) in the mouth of the Nyong River and Mpalla village (mostly young people interviewed from the Southern region) are familiar with only one or two commonly found mangroves. Also, more respondents from the Cameroon estuary are depending on mangroves for fuelwood (Rhizophora spp.) and housing (Rhizophora spp., Avicennia germinans (L.) Stearn and Nypa fruticans (Thumb.) Wurmb.) purposes, in contrast to Nyong River mouth and Mpalla village. Although local people perceived wood extraction as a greater disruptive factor, there are several causes for mangrove depletion in the Cameroon estuary. Among others, over-harvesting, clear-felled corridors, sand extraction and housing were found important. Furthermore, a decline in mangrove fauna composition (in terms of fishery products) was recorded in the Littoral as well as Southern regions. However, the causes of such perceived negative changes were not similar in both cases.

Conclusions: Findings of this study highlight the need to improve sustainable management of the mangrove ecosystems through afforestation (in large impacted areas), selective removal of senescent tree stems and branches (in little damage stands), regulating sand extraction and housing activities, and creating awareness and law enforcement.

\footnotetext{
* Correspondence: anfotabo@ulb.ac.be

'Laboratory of Systems Ecology and Resource Management, Département de Biologie des Organismes, Faculté des Sciences, Université Libre de Bruxelles-ULB, Avenue Franklin D. Roosevelt 50, CPI 169, B-1050 Brussels,

Belgium

Full list of author information is available at the end of the article
} 


\section{Background}

Deforestation is a major environmental concern that societies around the world are currently facing [1-4]. One of the most obvious cases pertains to mangrove forests that are found along the tropical and subtropical coastlines. Mangroves are disappearing at a rate greater than or equal to adjacent terra-firme rain forests [5]. The causes of loss have been mainly attributed to anthropogenic activities [6-8]. Indeed, mangrove wood products remain an important source of building and fuelwood material for coastal communities [9-14]. Therefore, in order to ensure that future generations enjoy the ecosystem services provided by mangroves $[15,16]$, it is fundamental to assess the environmental changes therein.

Though remote sensing and aerial photographs can supply valuable long-term data on forest cover changes, they are not always available for some parts of the tropics (e.g., Cameroon coast in Central Africa) where cloud cover is frequent. With a scarcity of such datasets in the developing countries, several researchers are now employing local knowledge as an alternative means of reconstructing changes in the mangrove forests $[17,4,18,19]$. The consistency of this alternative approach is related to the fact that local inhabitants can provide insight into certain environmental changes which may be missed by exact sciences alone [20-22]. Hence, local people's perception on long-term changes in the mangroves is of great importance [23].

In this study, residents of the Littoral and Southern region of Cameroon were surveyed for their forest products utilization and perception on mangrove cover changes. The aims were: (a) to confront the usage of mangrove wood products in the Southern Cameroon (close to the mouth of the Nyong River and Mpalla village (Kribi)) and the Littoral (Cameroon estuary) regions; and (b) to assess local resident's perceptions on environmental changes in the two regions.

\section{Methods}

\section{Study area}

Mangroves in the mouth of the Nyong River $\left(3^{\circ} 15^{\prime} \mathrm{N}\right.$ and $9^{\circ} 55^{\prime} \mathrm{E}$ ) and Mpalla village $\left(2^{\circ} 59^{\prime} \mathrm{N}\right.$ and $\left.9^{\circ} 55^{\prime} \mathrm{E}\right)$ are bordered by extensive terrestrial (evergreen) forest (Figure 1). These coastal ecosystems annually receive about $2870 \mathrm{~mm}$ of precipitation. The Cameroon estuary $\left(3^{\circ} 53^{\prime} \mathrm{N}\right.$ and $\left.9^{\circ} 38^{\prime} \mathrm{E}\right)$, with its two irregular seasons and a mean annual rainfall of $3988 \mathrm{~mm}$, shares more than $30 \%$ of its continental limit with Douala, the first most populated city in Cameroon [24]. The Littoral and Southern regions are also distinguishable in terms of mangrove area (small patches in the mouth of the Nyong River and Mpalla village and large units in the
Cameroon estuary) and anthropogenic disturbances (rural in Nyong and Mpalla village and peri-urban in the Cameroon estuary), and therefore makes this study highly relevant for appropriate conservation and management practices.

\section{Data collection}

The data were generated through conducting semistructured interviews with local residents (mostly fishermen living in the immediate vicinity of mangroves) and our field-based observations. Between 15 December 2007 and 25 February 2008, a semi-structured questionnaire (based on $[10,25]$ ) was used to investigate the two peripheral quarters of Douala (i.e., Youpwe and Bois de Singes), two large villages (Epassi and Mpalla), and three small neighbouring villages (Milende, Ngueh and Bwabe) (Figure 1). The number of respondents was 25, 16, 24, 30, 12, 6 and 7 at Youpwe, Bois de Singes, Epassi, Mpalla, Milende, Ngueh and Bwabe, respectively. Most interviews were done in French, except in Mpalla and Bwabe where a local language called 'Batanga' was used with the help of translator. Household visits were carried out at the end of the day after locals came back from their occupation/fishing activities. The households were sampled opportunistically (i.e., respondents encountered in the houses were interviewed whereas people away from their homes were not questioned). Nine homes were hostile to our visit and five people refused to answer.

In total, 120 questionnaires were carried out in this survey. Amongst these, 110 (60 in the Cameroon estuary and 50 at the mouth of the Nyong River and Mpalla village) were used for statistical analysis and 10 were discarded because of incoherent information. To avoid recurrent information, only one person ( $>20$ years of age) per house was questioned. The preference was given to elderly people who were living in the site for more than a generation and therefore could relate changes that occurred in adjacent mangroves to certain events or conditions. Interviewees were asked if the surrounding mangrove forest had increased, decreased or remained unchanged in cover. Likewise, an attempt was made to distinguish whether local informants perceived mangrove forests as less or more degraded over time. They were urged to provide the causes of the reported changes along with its consequences in their livelihood. Local inhabitants were also asked questions about any observed disturbances in the mangrove ecosystem.

A catalogue showing mangrove plants and their physiognomy, leaves, fruits and flowers was used (as described in $[10,25]$ ) to assess the level of each respondent's knowledge on mangrove species. Since most of the informants were unable to distinguish the 


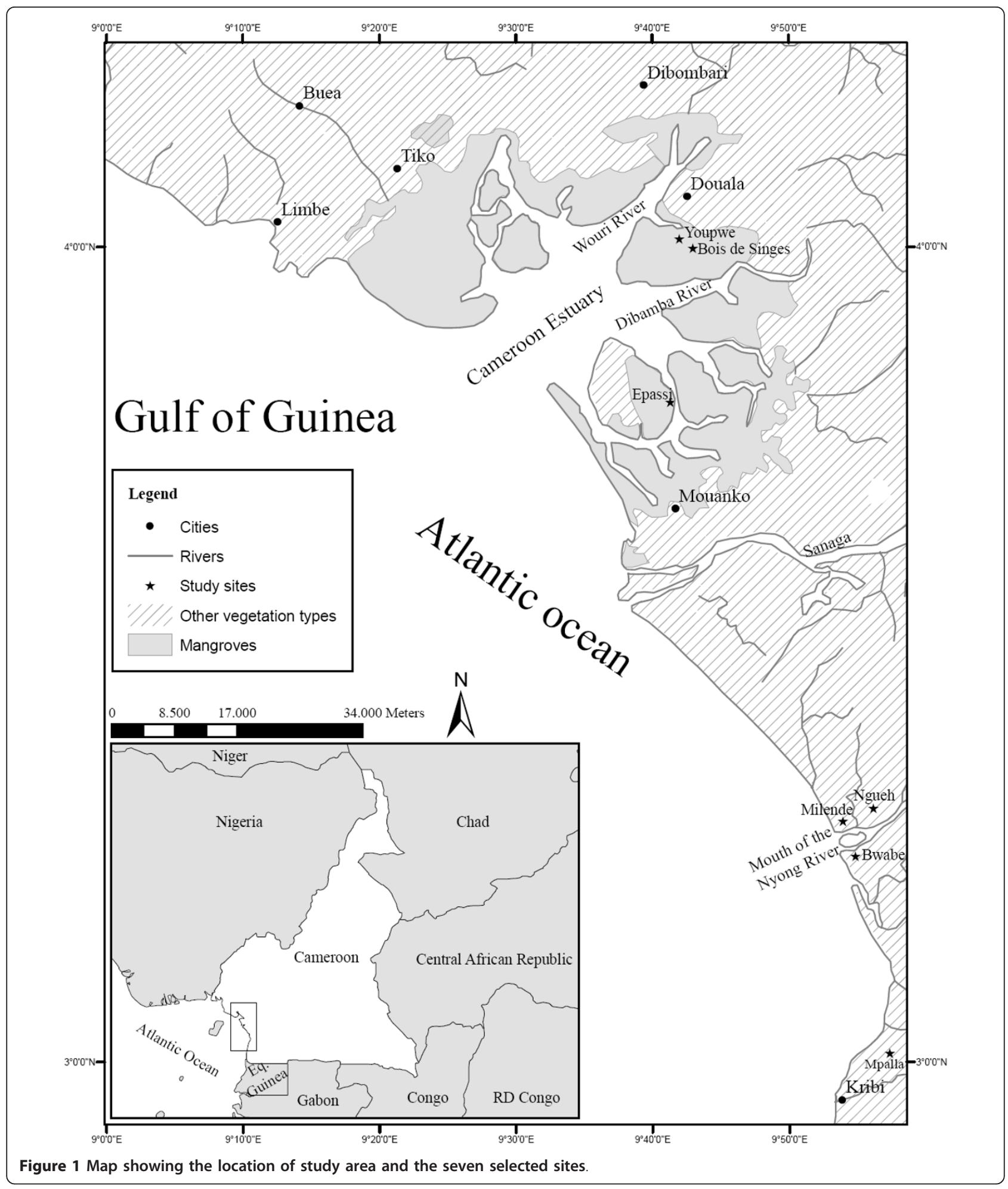

characteristic differences between Rhizophora racemosa Meyer- the dominant species in Cameroon mangrove forests ( $c f .[24,13]), R$. harrisonii Leechman and $R$. mangle L. (classification based on [26]), we have recorded only its genus name when they referred to any one of the above three species for use.

Data on local people's demography (e.g., age, gender, etc), along with plant vernacular names and their parts 
used for timber and non-timber forest products including ethnopharmacological (i.e., human diseases treated, methods of remedy preparation and administration) and chemical (e.g., dye preparation) usages, were gathered from the household interviews.

\section{Data analysis}

Chi-square tests $\left(\chi^{2}\right)$ (SPSS $v$. 16.0) were used: (a) to determine if there was any significant difference $(\mathrm{p}<$ 0.05 ) in mangrove use by region (i.e., Littoral and Southern), and (b) to confront the level of degradation reported by informants in the two regions. Principal component analysis (PCA) (a routine implemented in PRIMER v.6) was performed to assess the patterns of usage perceived as largely responsible for mangrove degradation in each region. It is important to highlight that the answers on the ethnobotanic (traditional species usage) section of the questionnaire reported by those people who could not even distinguish single species were not considered, whereas their general perceptions on environmental changes were taken into account.

\section{Results}

\section{Local people's knowledge on mangroves}

The majority of the informants were males and their age ranged between 21 and 72 years $(45.09 \pm 12.16$; mean \pm 1SD). In both parts, respondents referred to the mangrove forest as 'matanda', and identified Rhizophora tree as 'itanda' (Table 1). In the Cameroon estuary, 69.23\% of respondents (mostly elders) could distinguish two to four mangrove plants, whereas the informants (65.45\%) in the mouth of the Nyong River and the Mpalla village (mostly young people) are familiar with only one or two commonly found mangroves (e.g., Rhizophora spp. and Avicennia germinans (L.) Stearn).

\section{Utilization of mangrove resources}

During the field observation, a total number of five mangrove species namely, $R$. racemosa, $R$. harrisonii, $A$. germinans, Laguncularia racemosa (L.) Gaertn. f. and Nypa fruticans (Thumb.) Wurmb. were found in the Littoral region of Cameroon, and the same is true for the Southern region except that $R$. mangle replaced $R$. harrisonii.

In Cameroon, the mangrove products are used as fuelwood (e.g., charcoal making, cooking or heating of the traditional henhouses), construction materials, service wood, dye or medicine (Table 1). Within the Littoral region, the use of mangroves for fuelwood (Figure 2A), construction materials (Figure $2 \mathrm{~B}$ ) or service wood (Figure $2 \mathrm{C}, \mathrm{D})$ in Epassi is almost similar to Youpwe $\left(\chi^{2}=\right.$ 0.82 ; d.f. $=2 ; \mathrm{p}=0.13)$. With regard to the three aforementioned uses, mangrove wood collection is not significantly different in Bois de Singes and Youpwe $\left(\chi^{2}=\right.$ 5.18 ; d.f. $=2 ; \mathrm{p}=0.06)$. In contrast to Epassi, only few residents were using mangrove either as fuelwood, construction materials or service wood in Bois de Singes $\left(\chi^{2}\right.$ $=6.87$; d.f. $=2 ; \mathrm{p}=0.009)$ (Table 2$)$. In the Southern region, mangrove harvesting for the above purposes did not differ much between Mpalla and the mouth of the Nyong River (Milende, Ngueh and Bwabe) $\left(\chi^{2}=0.97 ; \mathrm{d}\right.$. f. $=2 ; \mathrm{p}>0.05)$.

Overall, the collection of mangrove wood products was found more important in the Cameroon estuary than in the mouth of the Nyong River and Mpalla village $\left(\chi^{2}=6.75\right.$; d.f. $\left.=2 ; \mathrm{p}<0.05\right)$ (Table 2$)$. Rhizophora

Table 1 Subsistence uses of mangrove woods in Littoral and South Cameroon.

\begin{tabular}{|c|c|c|c|}
\hline $\begin{array}{l}\text { Mangrove } \\
\text { taxa }\end{array}$ & $\begin{array}{l}\text { Local name } \\
\text { ('batanga', 'Duala') }\end{array}$ & $\begin{array}{l}\text { Part } \\
\text { used }\end{array}$ & Uses \\
\hline \multirow[t]{4}{*}{$\begin{array}{l}\text { Rhizophora } \\
\text { spp. }\end{array}$} & 'itanda' & stems & $\begin{array}{l}\text { commercial firewood and charcoal, precarious house construction (poles), plank-making, flagstone } \\
\text { support, fabrication of tables, chairs, boats/canoes immobilisation. }\end{array}$ \\
\hline & & branch & domestic firewood, fencing. \\
\hline & & bark & $\begin{array}{l}\text { malaria treatment (external usages), stop ping of external haemorrhages, stomach illness } \\
\text { (ingurgitation), tooth decay treatment, tainted fishing net. }\end{array}$ \\
\hline & & root & fabrication of shuttle. \\
\hline \multirow{3}{*}{$\begin{array}{l}\text { Avicennia } \\
\text { germinans }\end{array}$} & none reported & stems & commercial planks for construction, paddles, traditional boat/canoe construction, bench, chairs. \\
\hline & & branch & domestic firewood. \\
\hline & & $\begin{array}{l}\text { leaves, } \\
\text { bark }\end{array}$ & malaria treatment (external usages), smelly/stinky body. \\
\hline \multirow{2}{*}{$\begin{array}{l}\text { Laguncularia } \\
\text { racemosa }\end{array}$} & none reported & stems & Boat/canoe construction, paddles, firewood (household consumption). \\
\hline & & $\begin{array}{l}\text { leaves, } \\
\text { bark }\end{array}$ & treatment of measles, gonorrhoea, malaria, stomach illness. \\
\hline Nypa fruticans & 'Lende la djengu' & $\begin{array}{l}\text { leaves, } \\
\text { fruits }\end{array}$ & $\begin{array}{l}\text { mat confection, wall dressings. } \\
\text { house roofs decoration. }\end{array}$ \\
\hline
\end{tabular}




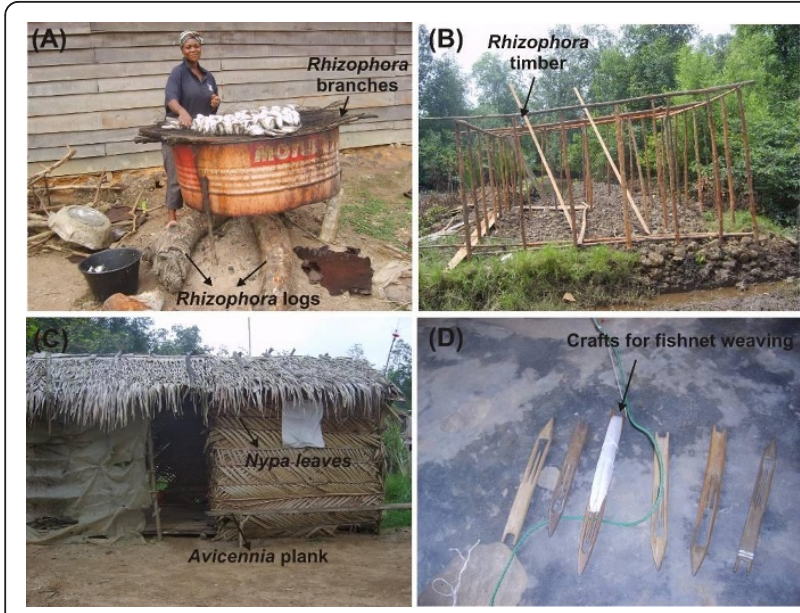

Figure 2 Photographs illustrating different mangrove uses in Cameroon: (A) Mangrove poles obtained from Rhizophora spp. are used for fish smoking ready to sell in the local market (Youpwe). (B) Use of Rhizophora small timber for precarious house building at Youpwe. (C) N. fruticans leaves used for walls covering at Epassi. (D) 'Shuttle' crafted from Rhizophora prop roots at Mpalla village (Kribi). (Photographs by ANA).

timber was used for house construction, especially in the Cameroon estuary (Table 1) (Figure 2B). The wall dressings and planks were obtained from Rhizophora spp. and A. germinans trunks. N. fruticans leaves were also used for wall dressings. In order to reduce the entry of air currents inside the precarious houses (in Epassi village), the walls are first covered by plastic sheets and then by $N$. fruticans leaves (Figure 2B, C). Rhizophora trunks constituted an important component of traditional chairs, benches and tables, while A. germinans stems are used for canoe construction and paddle fabrication. The latter two wood products were also obtained from L. racemosa trunks.

There were no significant differences between the two regions in terms of mangrove usage for medicine and/or dye for clothes or nets $\left(\chi^{2}=0.46\right.$; d.f. $\left.=1 ; \mathrm{p}>0.05\right)$ (Table 2). The collection and transformation of mangrove plants into medicinal products is usually done by women. However, mangrove medicine is popular and in use only at the wedged zones like Epassi, Milende, Bwabe and Ngueh. A. germinans leaves and bark were used to treat malaria patients. In this context, the bowl or pot with boiled water and A. germinans leaves/bark, together with the sick person, are covered by a thick blanket for inhaling. The same technique was also applied to cure measles and gonorrhoea, but with the leaves and bark of L. racemosa. According to local people, high perspiration could even eliminate bad odour from the patient's body. The decoction after boiling Rhizophora bark was used to stop external haemorrhages and to cure tooth decay. The usage of mangrove chemicals was particularly reported from Mpalla, Epassi and Milende. The liquid obtained from fresh Rhizophora bark is used to dye and preserve faded clothes and cotton fishing nets, the latter of which was also reported to attract more fish.

The tool 'shuttle' for weaving fishnets is locally made from Rhizophora prop roots (Figure 2D). They are crafted by artisans who were not always fishermen (Figure 2D). The shuttle's central part, which was empty except for a thin axis, was used to spin around fishing

Table 2 Mangrove wood products used in different sites. Comparisons in mangrove uses for fuelwood, house construction and service wood are made within and between the two regional sites.

\begin{tabular}{|c|c|c|c|c|c|c|}
\hline \multirow[t]{2}{*}{ Sites } & \multirow[t]{2}{*}{ \# Question-naires } & \multicolumn{5}{|c|}{ Mangrove uses } \\
\hline & & Fuelwood & Construction & Service wood & Medicinal & Chemical \\
\hline \multicolumn{7}{|l|}{ LITTORAL REGION } \\
\hline \multicolumn{7}{|l|}{ Cameroon estuary } \\
\hline Youpwe & 20 & 16 & 10 & 6 & 0 & 0 \\
\hline Bois de Singes & 16 & $6^{*}$ & $0^{*}$ & $0^{*}$ & 0 & 0 \\
\hline Epassi & 24 & 24 & 16 & 15 & 3 & 3 \\
\hline Total & 60 & $46^{*}$ & $26^{*}$ & $21^{*}$ & 3 & 3 \\
\hline \multicolumn{7}{|l|}{ SOUTHERN REGION } \\
\hline \multicolumn{7}{|c|}{ Mouth of Nyong River } \\
\hline Milende & 12 & 6 & 1 & 3 & 3 & 1 \\
\hline Ngueh & 6 & 0 & 0 & 2 & 1 & 0 \\
\hline Bwabe & 7 & 2 & 1 & 0 & 4 & 0 \\
\hline \multicolumn{7}{|l|}{ Kribi } \\
\hline Mpalla & 25 & 8 & 2 & 10 & 0 & 3 \\
\hline Total & 50 & 16 & 4 & 15 & 8 & 4 \\
\hline
\end{tabular}

Areas showing significant difference in mangrove uses are represented in bold with similar font colours. Values represent the number of respondents indicating that they use mangrove plants $(n=110)$.

${ }^{*} \mathrm{p}<0.05$. 
thread, and the entire tool was then used with the concave extremity to weave the fishing net. These shuttles are also available in the local market at Mpalla village with a price ranging from 0.30 to 0.45 EUR $(0.35 \pm 0.05$ EUR) (the exchange rate at the time of data collection was 1 EUR = 655.95 FCFA).

\section{Environmental changes in mangroves \\ Perceived changes to mangrove stands}

According to local people, the mangrove forests in Mpalla (Kribi) and in the mouth of Nyong River were not as severely degraded as in the Cameroon estuary $\left(\chi^{2}\right.$ $=67.94 ;$ d.f. $=2 ; \mathrm{p}<0.001)($ Table 3$)$. Here, more than half of the interviewees $(66.15 \%)$ reported considerable damage to mangroves (Table 3). On one hand, they recounted the loss of mangroves in some areas due to anthropogenic activities, and on the other hand they referred to natural degradation of the remaining stands. About a third of the population (32.31\%) supported that mangroves were not threatened and therefore remain unchanged, whereas a small minority (1.54\%) perceived mangrove degradation only slightly.

In the Cameroon estuary, several informants perceived mangrove wood extraction as a major disruptive factor. They all agreed to the fact that their own houses were constructed in the place(s) of mangroves. An important part of these participants ranked housing activity as a second threat. Though all respondents generally agreed with the ecological importance of mangrove (e.g., coast stabilization), they declared that this ecosystem is the only place where they could go for clear felling and free housing. Besides this assertion, other residents reported that the daily dumping of untreated domestic wastes could contribute to mangrove degradation locally. However, significant evidence of forest degradation was not observed in and around the concerned areas by the authors. Respondents had an opinion of less potential damage to mangroves with sand extraction (Figure 3A) since they disturb only substratum. It is also important to highlight that the areas (up to a distance of $3 \mathrm{~km}$ ) reported with municipal and domestic pollution are free from sand extraction activities.

In the mouth of the Nyong River and the Mpalla village, about $56.36 \%$ of respondents indicated that the existing mangroves were less impacted (Table 3 ). At the same time, a few residents from Mpalla explained that

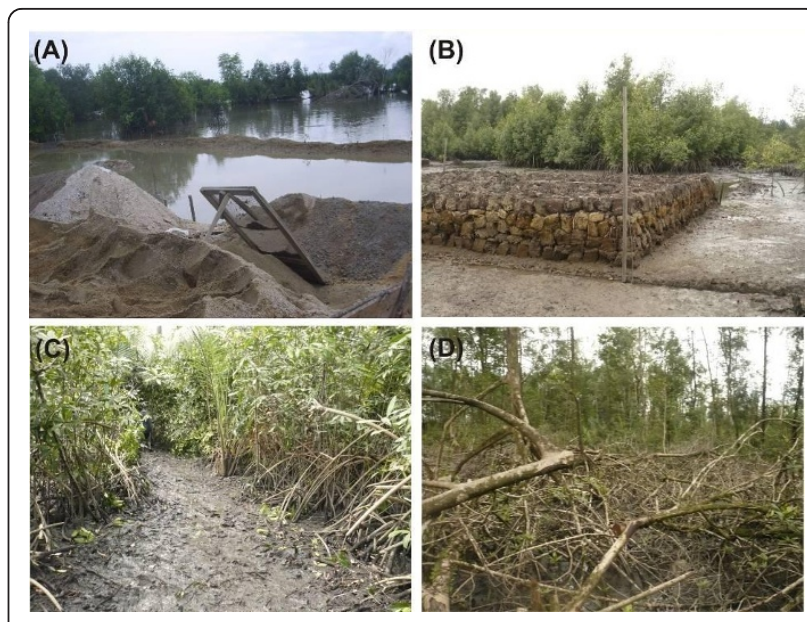

Figure 3 Mangrove land degradation in Cameroon: (A) Sand extraction within mangrove forest. The background shows uncut sparse adults trees. (B) Elevated areas of previously cleared mangrove stands waiting for housing. (C) Clear-felled corridor within the mangrove used for wood transport or as access path. (D) Complex of cut branches and prop roots (Rhizophora spp.) left in situ. (Photographs by ANA).

the fringe mangroves (bordering the sea) have been cleared by the foreign residents for land development projects. More than one-third (41.82\%) of the Southern informants still argue that the mangrove was less disturbed, while some residents of the latter category admitted that they occasionally cut mangrove trees growing in the immediate vicinity of their houses. In contrast, several fishermen in Mpalla village indicated that they were no longer able to reach to some of their old fishing grounds due to extensive growth of Rhizophora spp. prop roots and mud deposition along the channels. Indeed, people of this region clearly stated that they often prefer non-mangrove species (e.g., Lophira alata C.F. Gaertn. locally called as 'bojambi' or 'azobé"), with nearly the same calorific value as Rhizophora spp., for fuelwood.

The other non-reported, but field-observed, anthropogenic activities such as digging, landfill, dyke construction and large clear-felling would also contribute to mangrove degradation. In this case, the mangrove trees are uprooted and then filled with sediment (brought from nearby areas) to make those places suitable for housing (Figure 3B). Interviewees claim that these

Table 3 Local residents' perception of changes occurred in mangroves $(n=120)$.

\begin{tabular}{|c|c|c|c|c|}
\hline \multirow[t]{2}{*}{ Sites } & \multirow[t]{2}{*}{ Number of respondents } & \multicolumn{3}{|c|}{ Reported level of degradation } \\
\hline & & No change & Little & Large \\
\hline Cameroon estuary & 65 & $21(32.31 \%)$ & $1(1.54 \%)$ & $43^{* *}(66.15 \%)$ \\
\hline Mouth of Nyong River and Mpalla village & 55 & $23(41.82 \%)$ & $31(56.36 \%)$ & $1(1.82 \%)$ \\
\hline
\end{tabular}

${ }^{* *} p<0.001$. Values in parentheses indicate percentage of the respondents per type of perception per site. 
elevated areas could also protect their homes from (daily) tidal inundation. Another notable anthropogenic factor observed in Youpwe and Epassi, but not stated by informants, was the clear-felling of young mangrove trees (in $1.5 \mathrm{~m}$ width as a corridor) from inside the forest to the water channel(s) where they anchor boats (Figure 3C). In order to facilitate wood transportation, big logs were progressively pushed on mud along the clear-felled corridors. These corridors are also used as pathways later on by several loggers and local people. Unlike large stems of Rhizophora which were cut, split and transported for commercial purposes, their branches and stumps (with under-ground roots) are usually left in the field (Figure 3D).

The PCA with perceived causes of mangrove degradation in each site explained a total variability of $71.30 \%$ on axis-1 (i.e., eigenvalue of 7.03 ), and $26.30 \%$ on axis- 2 (i.e., eigenvalue of 2.59) (Figure 4). The linear coefficient of original variables (perceived causes) making up PCA revealed that the respondents in Epassi saw logging and

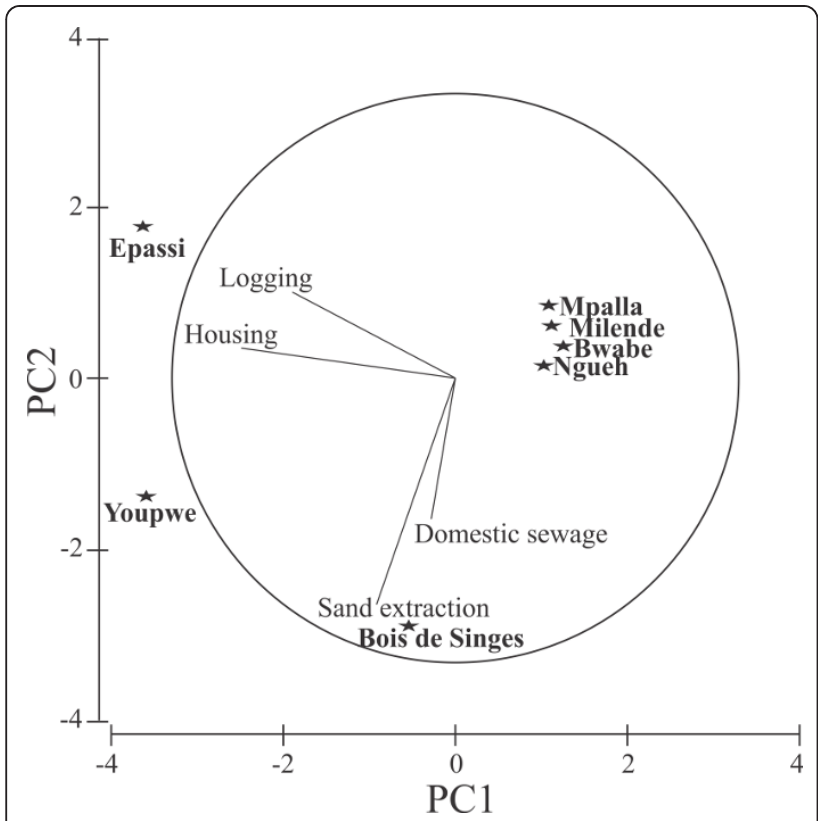

Figure 4 Principal Component Analysis of the perceived causes of mangrove degradation. It can be observed that each sample site in the Cameroon estuary (i.e., Epassi, Youpwe and Bois de Singes) is located close to its major degradation threat perceived. Nevertheless, the four sites on the top right corner (Mpalla, Milende, Bwabe and Ngueh) are seen less influenced by those four recognized mangrove threatening factors. Each star indicates the position of its respective sampling site in the PCA plane with reference to the perceived causes of mangrove degradation. The length of each vector line represents the importance of that particular variable's contribution to the PCA axis. The circle represents the graphical illustration of the correlation between the variables and the principal components. (This analysis does not take into account data obtained from field observation). housing (clustered on negative and positive sides of the both axes) as the main causes of mangrove degradation (Figure 4). In contrast, Bois de Singes was characteristic of the mangrove damages from municipal/domestic sewage pollution and sand extraction (clustered on lower parts of the axes). The informants at Youpwe site also perceived mangrove degradation as a consequence of housing and sand extraction (standing in-between Epassi and Bois de Singes). The Southern villages were all characterized by few concerns of degradation in mangroves, and clustered along the upper parts of the two principal components (i.e., PCA 1 and 2).

\section{Perceived changes in faunal composition of mangroves}

Although there were few logging activities in the mouth of the Nyong River, local people unanimously shared the opinion that trawler activities along the shore resulted in a decline in local fish catch inside the mangroves. This negative change was reinforced by the increased number of local fishermen. A decrease in the population of silurid, tilapia, mullets, shrimp, oyster and crab species, as stated by informants in the Mpalla village, was probably related to changes (e.g., siltation, reduced water circulation, etc) that occurred in the waterways. Though such decrease in mangrove faunal composition was recorded in the Littoral region, many interviewees linked it to the anthropogenic disturbances prevailing (e.g., harvesting, clear-felling, domestic sewage, pollution and sand extraction).

\section{Discussion}

\section{Mangrove uses}

Almost in every tropical and sub-tropical regions of the world, mangrove forests are widely harvested for different purposes $[6-8,10,13,24,27,28]$. In the Cameroon coastal regions, we found that stems obtained from $R h i$ zophora spp. and A. germinans are commercially important whereas their branches, in a few cases, were preferred for domestic utilization. The choice here for making those houses with small Rhizophora trees was based on its aesthetic value, availability, easiness to harvest and rot-resistance characteristics. Studies have documented that different mangrove species have different wood properties, making some more suitable than others for specific uses [8]. The stems of Rhizophora, characterized by its hard nature and richness in tannins, were perceived to be highly marketable goods for their potential use as firewood, charcoal and construction materials [9]. This wood is less appropriate for plankmaking than that of $A$. germinans, the latter being easier to split. Except in Epassi village (located $25 \mathrm{~km}$ away from Douala city), none of these two species were used for 'banda' construction (a table-like structure made from mangrove timber to smoke fish) as recorded previously by Nfotabong Atheull et al. [13] in the Douala- 
Edea reserve. However, instead of 'banda', the locals in Youpwe are using hollow iron drums (with its upper surface covered by Rhizophora branches) for fish smoking. The advantage with this kind of oven is said to be for keeping the smoked fish warm for longer durations.

Although there were no reports on the use of Rhizophora prop roots for 'shuttle' fabrication in the Littoral region, this is an activity carried out by some fishermen in Mpalla village. The strength and durability of the 'shuttle' reduced the frequency of prop root harvesting (about two prop roots per adult tree are cut) and tree felling. In addition, some artisans stated that their frequency of visits to the mangrove was limited because of the harsh environment. While both leaves and bark of $A$. germinans and $L$. racemosa are used in ethnopharmaceutical purposes, only that of Rhizophora bark serves medicinal and chemical purposes widely (Table 1 ). Similar uses of $A$. germinans, $L$. racemosa and Rhizophora have been reported by Kovacs [17] and Hernández-Cornejo et al. [6]. The bark of the above species is an excellent remedy for curing several diseases (malaria, measles and gonorrhoea) because of its rich soluble tannins [29] which may inhibit microbial activity [30]. Similar chemical usage (for dye preparation) of the barks obtained from Rhizophora and Ceriops decandra (Griff.) Ding Hou was also reported from Coringa mangroves in the Godavari Delta, India [25].

\section{Perceived environmental changes in mangroves}

Local people settled within or around the mangroves forests can provide information that contribute to the identification and/or evaluation of factors inducing environmental disturbances in mangrove forests (see $[4,11])$ since their observations span over a long-term [31]. Their perceived degree of mangrove damage may vary depending on location and place of the mangrove stands studied. For instance, the local residents' perceptions on environmental changes differ between the Littoral and Southern parts of the Cameroon coastlines (see results).

\section{Mangrove changes in the Littoral region}

In the case of Cameroon estuary, high rate of unemployment coupled with lax government enforcement and the peri-urban situation of mangroves favoured the large degradation of forests (Figure 5). The local loggers, while waiting for a formal job, often cut mangrove wood for commercial utilization [13]. As mentioned in the results, the majority of local people perceived that wood harvesting and house construction are significant causes of mangrove damage. Instead of focusing on both causative factors, it is always worth to highlight the combination of issues which are truly responsible for changes in the mangrove forests (Figure 5).

Another possible cause for extensive mangrove degradation in the Cameroon estuary is population growth, which can uplift the anthropogenic pressure on adjacent ecosystems $[24,32,33]$. This threat is of great concern since a considerable proportion of informants living in the Littoral region stated that they can liberally use mangrove areas for housing.

The local residents recognized that some mangrove stands were already replaced by houses. They further explained that house construction often starts with dyke enclosures (to reduce water supply), then mud cracking and finally tree clear-felling. With regard to these statements and the findings of Din and Blasco [34], anarchic urbanization constitutes an additional significant threat to mangrove degradation in the Cameroon estuary (Figure 5). The extent of subsequent damage depends on the intensity, persistence and periodicity of forest disturbance $[35,36]$, as well as the type of anthropogenic activity carried out. Likewise, cutting could also lead to a dramatic effect from which recovery may be slow or even impossible $[8,12,16,28,35]$. The speed of recovery is function of the forest type affected and the density of seedlings and established propagules prior to cutting. For instance, in disturbed Rhizophora zones, cut branches and prop roots left in the site, often trap mangrove propagules and prevent their dispersal into the inner disturbed zones. However, this phenomenon is less pronounced within the disturbed monospecific stands of $A$. germinans where its seed retention by cut branches and pencil roots is limited.

Contrary to informant information, the impact of untreated anthropogenic sewage pollution on mangroves cannot be proved with the current observations. In addition, some studies have indicated an increase of mangrove [37,38] and shrimp [39] growth, with no apparent negative effects $[23,40,41]$.

A detailed analysis of the PCA has shown that the perceived causes of mangrove damage differ across the sample sites. In the Cameroon estuary, the site separation is probably due to higher heterogeneity amongst the sample sites with respect to some patterns of use. For example, people from the Bois de Singes are only concerned about municipal/domestic sewage pollution. Such kind of pollution is common in mangroves of East Africa [23]. Residents of the aforementioned site, like those of Youpwe, also qualified sand extraction as a threat to mangrove. But Youpwe residents attributed a similar potential threat to sand extraction and housing. Likewise, sand extraction and housing were rated almost equitably in Epassi. Therefore, the discrepancies amongst sites likely denote the differences in site locations. For instance, in a non-urban site like Epassi, sand extraction and municipal/domestic sewage pollution are unknown activities and accordingly weighted more the perceived negative effects of logging and housing. However, in the peri-urban site such as Youpwe, the diverse 


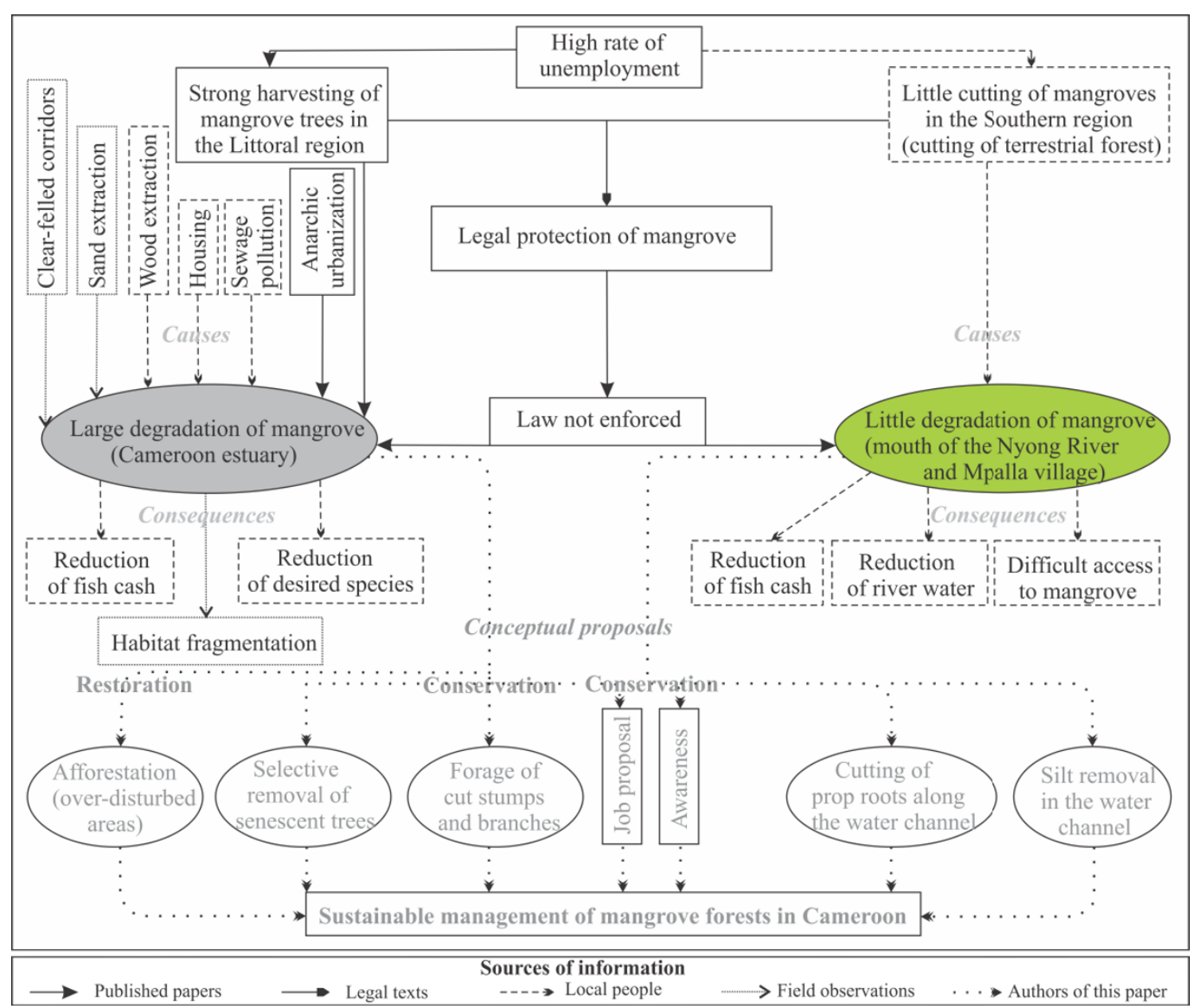

Figure 5 Flow chart showing the causes of mangrove degradation as well as remedies (conceptual proposals) for its proper conservation and management strategies in Cameroon. Each source of information is represented by different types of arrows. The causes as well as consequences of large (Littoral region) or little (Southern region) degradation of mangrove forests are also differentiated.

perceived threats could explain the intermediate position of this site. Based on our field observations, clear-felled corridors in the mangrove areas, sand extraction, urban expansion and housing and associated activities (dyke construction, large clear-felling and digging) could be seen as major threats creating almost irreversible changes in the species composition and distribution. Of course, it is clear from the results that clear-felled corridors could lead to the fragmentation of mangrove habitats in Youpwe and Epassi. Moreover, in some mangrove stands at Bois de Singes, the destruction of propagules by sand extraction might prevent natural regeneration, which could be masked by the continued presence of patched trees (see Figure 3A). This was similar to what Lewis III [42] observed and quoted it as 'propagule limitation'. Notice that the concerns are not restricting to the propagules alone since residents in the Littoral region recognized low fish production (including gastropod, bivalves and crabs) with high anthropogenic disturbances.

\section{Mangrove changes in the Southern region}

Similar to the Littoral region, there is also high unemployment rate and no enforcement of laws protecting mangroves in the Southern region. Yet, mangroves in the mouth of Nyong River and Mpalla village were seen degraded only slightly (Figure 5 ). This is clearly illustrated in the PCA by a grouping of sites sampled in the Southern region. The low perceived threat to mangroves might be due to less dependence of residents on this intertidal forest. In fact, the Mpalla and other villages in the mouth of the Nyong River are surrounded by terrestrial rain forest from which the local people obtain timber and non-timber forest products (Figure 5).

In the locations where there is an abundant supply of hardwood timber from other forest types (e.g., Australia), the use of mangrove wood has been very limited 
and several mangrove forests remain well conserved [7]. In the Mpalla village, this kind of situation must be responsible for rapid growth of Rhizophora prop roots and siltation (reducing the width and depth of water channels), and ultimately less access to some traditional fishing grounds. This is in strong opposition with the mangrove of Nziou (Kribi located, $3 \mathrm{~km}$ from Mpalla) which has been deforested for land development projects (pers. obs.). However, the reported changes in Mpalla village also have a natural meaning, as it is the only water channel carrying seawater into mangrove (the small creek mouth) and further upstream with narrowing width. Interestingly, the fishermen have also learnt to manage this phenomenon. Indeed, they damup the small creek mouth in November (beginning of dry season) and open it in December (mid dry season) to catch the fish that were seeking refuge or that have been trapped in the mangrove and try to migrate back to the ocean.

\section{Mangrove restoration and conservation}

Overall, the local communities are aware of changes that occurred in their adjacent mangrove forests and most of them were willing to abandon mangrove cutting provided they find alternatives. In this context, development of rural commercial farming as one of the possible alternate jobs to mangrove cutting might reduce anthropogenic pressure on the Cameroon mangrove forests. On one hand, by diminishing the rural exodus from villages to Douala city, human pressure on the peri-urban mangrove resources may be reduced. One the order hand, as stated by Linares [43], many local people currently degrading and destroying the peri-urban mangrove ecosystems could return to their original communities to develop farming activities. In addition, better access to education and credit (a scheme designed to promote individual entrepreneurship) along with the adoption of specialized fisheries might reduce the extraction of fuelwood and clearing for house construction [44]. Moreover, the development of ecotourism inside the mangrove forests might imply a progressive livelihood diversification away from the traditional overexploitation of these intertidal forests.

For the Cameroon estuary, the restoration or rehabilitation might only be considered as a priority when mangrove forests have been cut to such an extent that it could no longer self-correct or self-renew (cf. [45]). Under such conditions, an afforestation policy for the mangrove ecosystem involving its reproduction and growth must be undertaken [46]. In this case, reforestation projects should take into account the soil characteristics ( $c f$. [47]) and seedling availability. However, in the zones under less harvest pressure, efforts should only emphasize on selective removal of senescent tree stems and branches, natural regeneration and awareness of local residents on the importance of mangrove ecosystems (Figure 5). Local people should look for stumps and cut down branches previously left in the field and thereby reduce levels of cutting. Considering the fact that changes in hydrology could impact mangroves at some distance, causing the gradual die-back of particular species or entire stands [48], expanded Rhizophora prop roots and accumulated mud in the waterways at Mpalla (Southern region) should be regulated through selective cutting and digging processes (for silt removal in the channel).

\section{Conclusions}

This survey provided details on the importance of Cameroon mangrove forests in local livelihoods, along with the people's perceptions on environmental changes that have occurred in these coastal habitats. Both large and little damage to existing mangrove stands in the Littoral and Southern region of Cameroon were clearly identified through both questionnaire and field-based observations. It is a complex mix of causes (i.e., overharvesting, housing, clear-felled corridors and sand extraction) that have led to environmental changes in the mangroves of Cameroon estuary. In contrast, the little damage of mangrove forests around the mouth of Nyong River and Mpalla village (Kribi) is due to smallscale demographic pressure and its proximity to terrestrial (evergreen) forest from where the local people collect wood for their daily subsistence needs. Although the two aforementioned mangrove stands are rather less damaged, there is however an urgent need to regulate the anthropogenic pressure in the Cameroon estuary. The development of management strategies should also consider the ecological and economic significance of mangrove products $[11,16]$. The enforcement of laws that protect mangrove ecosystems, combined with high awareness and alternative job proposals, are determinant for conservation of these coastal ecosystems.

\section{Acknowledgements}

We gratefully acknowledge the National Hydrocarbon Corporation (NHC) of Cameroon and Cameroon Oil Transportation Company (COTCO) for funding. We also extend our gratitude to the Bureau des Relations Internationales et de la Coopération (BRIC) of the Université Libre de Bruxelles, funds De Meurs-François and David \& Alice Van Buuren for providing additional financial supports. Thanks are also due to the local chiefs of Mpalla, Milende, Ngueh, Bwabe, Epassi, Bois de Singes and Youpwe. Finally, the authors acknowledge the constructive and positive comments provided by the two anonymous reviewers.

\section{Author details}

${ }^{1}$ Laboratory of Systems Ecology and Resource Management, Département de Biologie des Organismes, Faculté des Sciences, Université Libre de Bruxelles-ULB, Avenue Franklin D. Roosevelt 50, CPI 169, B-1050 Brussels, Belgium. ${ }^{2}$ The University of Douala, Faculty of Science, Department of Botany, P.O. Box 8948 Douala, Cameroon. ${ }^{3}$ University of Yaoundé I, Faculty of 
Science, Department of Plant Biology, P.O. Box 812 Yaoundé, Cameroon. ${ }^{4}$ Laboratory of Plant Biology and Nature Management, Mangrove Management Group, Vrije Universiteit Brussel-VUB, Pleinlaan 2, B-1050 Brussels, Belgium. ${ }^{5}$ Institute of Oceanography, Universiti Malaysia Terengganu - UMT, 21030 Kuala Terengganu, Malaysia.

\section{Authors' contributions}

ANA conducted interviews and field observations, participated in its design, performed the statistical analysis and made interpretation of results and draft the final version of the manuscript. ND participated in the design and final draft of the manuscript. EKGL conducted interviews and field observations. BS and NK participated in the design and final drafts of the manuscript. FDG conceived and supervised the study, participated in its design, made data interpretation and participated in all drafts of the manuscript. All authors read and approved the final version of the manuscript.

\section{Competing interests}

The authors declare that they have no competing interests.

Received: 31 May 2011 Accepted: 6 December 2011

Published: 6 December 2011

\section{References}

1. Ehrlich PR, Mooney HA: Extinction, substitution, and ecosystem services. BioScience 1983, 33:248-254.

2. Houghton RA: The worldwide extent of land-use change. BioScience 1994, 44:305-313.

3. Dobson AP, Bradshaw AD, Baker AJM: Hopes for the future: restoration ecology and conservation biology. Science 1997, 277:515-522.

4. Kovacs JM: Perceptions of environmental change in a tropical coastal wetland. Land Degradation and Development 2000, 11:209-220.

5. Valiela I, Bowen JL, York JK: Mangrove forests: one of the world's threatened major tropical environments. Bioscience 2001, 5:807-815.

6. Hernández-Cornejo R, Koedam N, Ruiz Luna A, Troell M, Dahdouh-Guebas F: Remote sensing and ethnobotanical assessment of the mangrove forest changes in the Navachiste-San Ignacio-Macapule lagoon complex, Sinaloa, Mexico. Ecology and Society 2005, 10(1), art 16.

7. FAO: The world's mangroves 1980-2005 Food and Agriculture Organisation of the United Nations Forestry paper 153, Rome; 2007

8. Walters BB, Rönnbäck P, Kovacs JM, Crona B, Hussain SA, Badola R, Primavera JH, Barbier E, Dahdouh-Guebas F: Ethnobiology, Socioeconomics and Management of Mangrove Forests: A Review. Aquatic Botany 2008, 89:220-236

9. Bandaranayake WM: Traditional and medicinal uses of mangroves. Mangroves and Salt Marshes 1998, 2:133-148.

10. Dahdouh-Guebas F, Mathenge C, Kairo JG, Koedam N: Utilization of mangrove wood products around Mida Creek (Kenya) amongst subsistence and commercial users. Economic Botany 2000, 54:513-527.

11. Walters BB: Ecological effects of small-scale cutting of Philippine mangrove forests. Forest Ecology and Management 2005, 206:331-348.

12. UNEP: Mangroves of Western and Central Africa UNEP-Regional Seas Programme/UNEP-WCMC; 2007.

13. Nfotabong Atheull A, Din N, Longonje SN, Koedam N, Dahdouh-Guebas F: Commercial activities and subsistence utilization of mangrove forests around the Wouri estuary and the Douala-Edea reserve (Cameroon). Journal of Ethnobiology and Ethnomedicine 2009, 5:35.

14. Feka NZ, Manzano MG, Dahdouh-Guebas F: The effects of different gender harvesting practices on mangrove ecology and conservation in Cameroon. International Journal of Biodiversity Science, Ecosystem Services \& Management 2011

15. Duke NC, Meynecke JO, Dittmann S, Ellison AM, Anger K, Berger U, Cannicci S, Diele K, Ewel KC, Field CD, Koedam N, Lee SY, Marchand C, Nordhaus I, Dahdouh-Guebas F: A world without mangroves? Science 2007, 317:41-42.

16. Barbier EB, Sally DH, Chris K, Evamaria WK, Adrian CS, Brian RS: The value of estuarine and coastal ecosystem services. Ecological Monographs 2011, 81:169-193.

17. Kovacs JM: Assessing mangrove use at the local scale. Landscape and Urban Planning 1999, 43:201-208.
18. Kovacs JM, Malczewskit J, Flores-Verdugo F: Examining local ecological knowledge of hurricane impacts in a mangrove forest using an Analytical Hierarchy Process (AHP) Approach. Journal of Coastal Research 2004, 20:792-800.

19. Dahdouh-Guebas F, Koedam N: Long-term retrospection on mangrove development using transdisciplinary approaches: A review. Aquatic Botanic 2008, 89:80-92.

20. Rochet MJ, Prigent M, Bertrand JA, Carpentier A, Coppin F, Delpech JP, Fontenelle G, Foucher E, Mahé K, Rostiaux E, Trenkel VM: Ecosystem trends: evidence for agreement between fishers' perceptions and scientific information. ICES Journal of Marine Science 2008, 65:1057-1068.

21. Schaich $\mathrm{H}$ : Local residents' perceptions of floodplain restoration measures in Luxembourg's Syr Valley. Landscape and Urban Planning 2009, 93:20-30.

22. Agho K, Stevens G, Taylor M, Barr M, Raphael B: Population risk perceptions of global warming in Australia. Environmental Research 2010, 110:756-763.

23. Crona Bl, Rönnbäck P, Jiddawi N, Ochiewo J, Maghimbi S, Bandeira S: Murky water: Analyzing risk perception and stakeholder vulnerability related to sewage impacts in mangroves of East Africa. Global Environmental Change 2009, 19:227-239.

24. Din N, Saenger P, Priso RJ, Dibong DS, Blasco F: Logging activities in mangrove forests: A case study of Douala Cameroon. African Journal of Environmental Science and Technology 2008, 2:22-30.

25. Dahdouh-Guebas F, Collin S, Lo Seen D, Rönnbäck P, Depommier D, Ravishankar T, Koedam N: Analysing ethnobotanical and fishery-related importance of mangroves of the East-Godavari Delta (Andhra Pradesh, India) for conservation and management purposes. Journal of Ethnobiology and Ethnomedicine 2006, 2:1-24.

26. Tomlinson PB: The Botany of Mangroves Cambridge University Press; 1986.

27. Alongi DM: Present state and future of the world's mangrove forests. Environmental Conservation 2002, 29:331-349.

28. Walters BB: Patterns of local wood use and cutting of Philippines mangroves forests. Economy Botanic 2005, 59:66-76.

29. Walsh GE: Exploitation of mangrove. In Wet Coastal Ecosystems. Edited by: Chapman VJ. New York: Elsevier Science; 1977:

30. Wooller M, Smallwood B, Jacobson M, Fogel M: Carbon and nitrogen stable isotopic variation in Laguncularia racemosa (L.) (white mangrove) from Florida and Belize: implications for trophic level studies. Hydrobiologia 2003, 499:13-23.

31. Mitchell B: Resource and Environmental Management Addison Wesley Longman, Harlow; 1997.

32. Din N, Ngollo DE: Perspectives for Sustainable Management of Mangrove Ecosystems in Cameroon. European Tropical Forest Research Network NEWS 2002, 36:48-51.

33. Feka NZ, Manzano MJ: The implications of wood exploitation for fish smoking on mangrove ecosystem conservation in the South West Province, Cameroon. Tropical Conservation Science 2008, 1:222-235.

34. Din N, Blasco F: Mangrove of Cameroon, ecological statute and deforestation. In Geosciences in Cameroon. Edited by: Vicat JP, Bilong P. Yaounde (Cameroon): University press; 1998:15-22.

35. Hauff RD, Ewel KC, Jack J: Tracking human disturbance in mangroves: estimating harvest rates on a Micronesian Island. Wetlands Ecology and Management 2006, 14:95-105.

36. Ambastha KR, Hussain SA, Badola R, Roy PS: Spatial Analysis of Anthropogenic Disturbances in Mangrove Forests of Bhitarkanika Conservation Area, India. J. Indian Society of Remote Sensing 2010, 38:67-83.

37. Boonsong K, Plyatiratitivorakul S, Patanapompalboon P: Potential use of mangrove plantation as constructed wetland for municipal wastewater treatment. Water Sci Technol 2003, 48:257-266.

38. Mohamed MOS, Neukermans G, Kairo JG, Dahdouh-Guebas F, Koedam N: Mangrove forests in a peri-urban setting: the case of Mombasa (Kenya). Wetlands Ecology and Management 2009, 17:243-255.

39. Penha-Lopes G, Torres P, Cannicci S, Narciso L, Paula J: Monitoring anthropogenic sewage pollution on mangrove creeks in southern Mozambique: A test of Palaemon concinnus Dana, 1852 (Palaemonidae) as a biological indicator. Environmental Pollution 2011, 159:636-645.

40. Wong YS, Tam NFY, Lan CY: Mangrove wetlands as wastewater treatment facility: a field trial. Hydrobiologia 1997, 352:49-59. 
41. Vaiphasa C, de Boer WF, Skidmore AK, Panit-chart S, Vaiphasa T, Bamrongrugsa N, Santitamnont P: Impact of solid shrimp pond waste materials on mangrove growth and mortality: a case study from Pak Phanang, Thailand. Hydrobiologia 2007, 591:47-57.

42. Lewis RR III: Ecological engineering for successful management and restoration of mangrove forests. Ecological Engineering 2005, 24:403-418.

43. Linares OF: Going to the city....and coming back? Turnaround migration among the Jola of Senegal. Africa 2003, 73:113-132.

44. Conchedda G, Lambin EF, Mayaux P: Between land and sea: livelihoods and environmental changes in mangrove ecosystems of Senegal. Annals of the Association of American Geographers 2011, 101:1-26.

45. Bosire JO, Dahdouh-Guebas F, Walton M, Crona BI, Lewis RR III, Field C, Kairo JG, Koedam N: Functionality of restored mangroves: a review. Aquatic Botany 2008, 89:251-259.

46. Din N, Priso RJ, Kenne M, Ngollo DE, Blasco F: Early growth stages and natural regeneration of Avicennia germinans (L.) Stearn in the Wouri estuarine mangroves (Douala-Cameroon). Wetlands Ecology and management 2002, 10:461-472.

47. Kaly UL, Eugelink G, Robertson A: Soil conditions in damaged North Queensland mangroves. Estuaries 1997, 20:291-300.

48. Dahdouh-Guebas F, Hettiarachchi S, Lo Seen D, Batelaan O, Sooriyarachchi S, Jayatissa LP, Koedam N: Transitions in ancient inland freshwater resource management in Sri Lanka affect biota and human populations in and around coastal lagoons. Current Biology 2005, 15:579-586.

doi:10.1186/1746-4269-7-41

Cite this article as: Nfotabong-Atheull et al:: Assessing forest products usage and local residents' perception of environmental changes in periurban and rural mangroves of Cameroon, Central Africa. Journal of Ethnobiology and Ethnomedicine 2011 7:41.

\section{Submit your next manuscript to BioMed Central} and take full advantage of:

- Convenient online submission

- Thorough peer review

- No space constraints or color figure charges

- Immediate publication on acceptance

- Inclusion in PubMed, CAS, Scopus and Google Scholar

- Research which is freely available for redistribution

Submit your manuscript at www.biomedcentral.com/submit
Biomed Central 